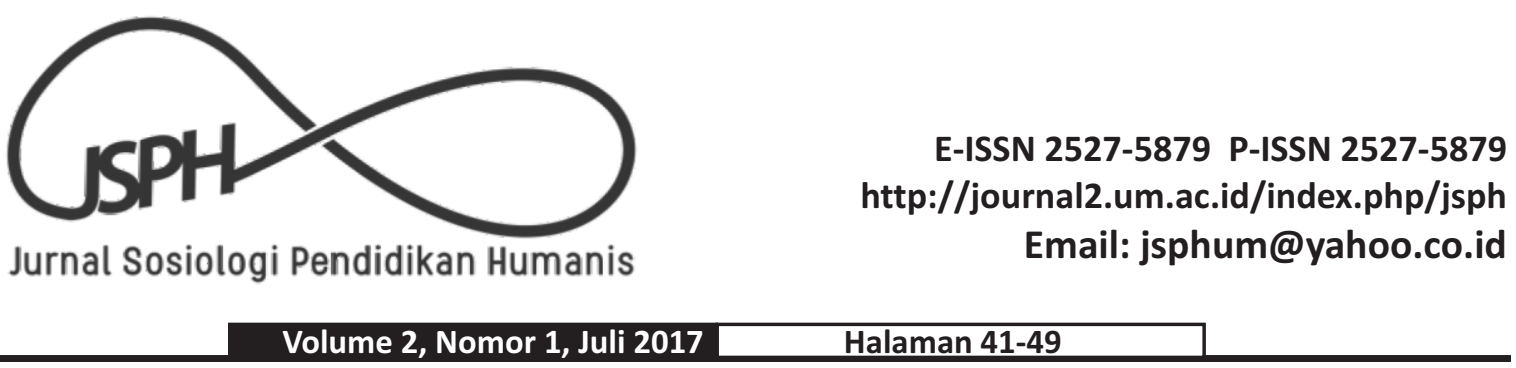

\title{
PENDIDIKAN KAUM TERTINGGAL DI SAMPANG
}

\author{
Ardhie Raditya \\ Program Studi Sosiologi, Departemen Ilmu Sosial, FISH-Unesa \\ Email : diditz.kristina@gmail.com, ardhieraditya@unesa.ac.id
}

\begin{abstract}
Abstrak
Sebagaimana tercantum dalam Perpres nomor 131/2015, Sampang tergolong salah satu daerah tertinggal di Indonesia. Fenomena ketertinggalan yang sangat mencolok di Sampang adalah aspek pendidikannya. Dengan menggunakan metode fenomenologi, pendidikan kaum tertinggal di desa Blu'uran, lebih spesifiknya di SDN Blu'uran 2, maka fenomena ketertinggalan tersebut tampak dalam beberapa hal. Pertama, para siswa dan orang tuanya tidak memiliki cita-cita dan masa depan ideal. Tujuan mereka bersekolah nyaris tanpa pengharapan. Kedua, kesuksesan pendidikan bukan ditentukan oleh faktor kepintaran (pènter), melainkan keberuntungan (pojur). Ketiga, kondisi sosial geografis dan tekanan keagamaan yang kuat memaksa masyarakat sekitar tidak memiliki kebebasan menentukan masa depan pendidikannya.
\end{abstract}

Kata Kunci: Pendidikan; Kaum Tertinggal; Sampang; Madura.

\section{MARGINAL PEOPLE EDUCATION IN SAMPANG}

\section{Abstract}

As stated in Perpres number 131/2015, Sampang is one of the least developed regions in Indonesia. This lag phenomenon is seen by the educational aspect. This phenomenon can be seen in SDN Bluuran 2 Sampang which appears in several ways: First, the students and their parents have no hope and ideal future. Their goals goes to school is without hope. Second, the success of education is not determined by factors cleverness, but luckiness. Third, the strong geographical and religious pressures force the surrounding communities to have no freedom to determine their educational future.

Keywords: Education; Marginal; Sampang; Madura. 


\section{LATAR BELAKANG}

Sampang merupakan bagian tidak terpisahkan dari pulau Madura. Posisi wilayahnya berada di antara kabupaten Bangkalan dan Pamekasan. Menuju ke Sampang membutuhkan waktu normal sekitar 3 jam dari arah kota Surabaya. Dibandingkan kabupaten sekitarnya, Sampang jarang dikenal orang luar Madura. Sampang dikenal publik karena pemberitaan media mengenai banjir saat musin hujan. Belakangan, Sampang menyita perhatian nasional karena mencuatnya konflik kekerasan kelompok SunniSyiah beberapa tahun silam. Kini, sampang kembali disorot dari aspek pembangunannya sejak dikeluarkannya Perpres nomor 131/2015 yang memposisikan Sampang sebagai bagian dari daerah tertinggal 2015-2019. Salah satu dasar status daerah tertinggal ini adalah minimnya kualitas pendidikan.

Berdasarkan data BPS provinsi Jawa Timur (Jatim) 2013/2014 menunjukkan bahwa sekolah menengah umum negeri dan swasta yang berada di di Madura berjumlah 45 di Bangkalan, 28 di Sampang, 46 di Pamekasan, serta 45 di Sumenep. Jumlah muridnya sebanyak 10.940 di Bangkalan, 7115 di Sampang, 10.568 di Pamekasan, dan 14.726 di Sumenep. Total gurunya secara berturut-turut di masing-masing daerah Madura adalah 880 orang (Bangkalan), 714 orang (Sampang), 1134 orang (Pamekasan), dan 1302 orang

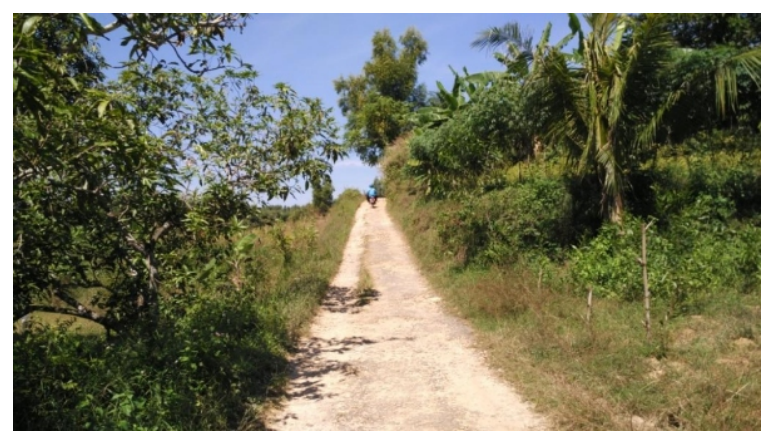

Gambar 1. Lokasi Menuju SDN Blu'uran 2 (Sumber: dokumen pribadi)

(Sumenep). Jika data statistik mengenai jumlah sekolah ini dijadikan rujukan, maka dari aspek pendidikannya Sampang cukup tertinggal daripada ketiga kabupaten lainnya di Madura.

Karena itulah, tulisan ini hendak membahas tentang persoalan pendidikan daerah tertinggal di Sampang dengan mengambil satu lokasi di SDN Blu'uran 2 yang berada di desa Blu'uran. Desa Blu'uran merupakan salah satu daerah konflik Sunni-Syiah yang hingga kini masih rawan. SDN Blu'uran 2 memang tidak terimbas secara langsung persoalan konflik sosial keagamaan tersebut. Meskipun demikian, keberlangsungan proses pendidikan di sana cukup menarik karena terjadi kompetisi yang sengit antara pendidikan umum dan pendidikan berbasis keagamaan. Seperti sekolah pada umumnya di desa Blu'uran, menuju ke sekolah ini membutuhkan waktu relatif lama. Sebab, akses jalan yang jauh dari memadai dan transportasi massal yang sangat terbatas. Dalam hitungan Saya bahwa dari pusat kota Sampang menuju ke sekolah dasar tertua di desa Blu'uran butuh waktu sekitar satu jam dengan menggunakan kendaraan bermotor roda dua. Apabila ditempuh melalui jalur utara kota Pamekasan karena letak geografisnya berbatasan dengan sebelah barat daya Pamekasan maka dibutuhkan waktu sekitar satu jam lebih lama. Yang sangat memprihatinkan, jarak rumah siswa dengan sekolahnya rata-rata lebih dari $2 \mathrm{Km}$ dan biasanya mereka tempuh dengan cara berjalan kaki. Oleh karena itu, tulisan ini mencoba mendeskripsikan bagaimanakah orang desa Blu'uran memaknai pendidikannya? Sekaligus, bagaimanakah fenomena sosial geografis di sana turut memberikan corak pendidikan masyarakatnya?

\section{METODE PENELITIAN}

Penelitian ini menggunakan metodologi kualitatif. Menurut Lexy J.Moleong (2006: 3) kualitatif sebagai prosedur penelitian menghasilkan data deskriptif berupa kata-kata tertulis maupun lisan dari orang-orang dan perilaku yang dapat diamati. Dengan demikian, kualitatif bisa disebut metode penelitian yang digunakan untuk meneliti kondisi objek alamiah, dimana peneliti sebagai instrumen kuncinya, analisis datanya bersifat induktif, dan hasil penelitian kualitatif lebih menekankan makna daripada generalisasi. Riset ini menggunakan pendekatan fenomenologi yang difokuskan pada studi kasus dengan mengambil lokasi SDN 2 Blu'uran yang terdapat pada desa Blu'uran. Pendekatan fenomenologis untuk mengungkap data secara mendalam mengenai aspek kesadaran manusia dengan dimensi sosial, historis, dan budaya di baliknya (Moustakas, 1994).

Sebagai daerah pedalaman yang rawan konflik-kekerasan efek dari kasus keagamaan aliran Suni-Syiah, kecurigaan masyarakat di desa Blu'uran terhadap 'orang luar' sungguh bisa dipahami. Meskipun Saya sendiri merupakan orang Madura, masyarakat di sana tidak mudah percaya begitu saja dengan kedatangan orang luar desanya. Banyak hal pemicunya. Tetapi, dari sekian banyak pemicu justru keengganan masyarakat di sana terhadap aktivitas penelitian dari orang luar, terutama luar Madura, merupakan pemicu terbesarnya. Karena, pengalaman mereka terhadap aktivitas penelitian mengenai tema konflik-kekerasan kasus SuniSyiah telah banyak menciptakan kekecewaan 
sebagian besar masyarakat sekitar. Bagi sebagian besar masyarakat menganggap bahwa aktivitas penelitian yang seringkali dilakukan untuk menjawab daftar persoalan kasus Suni-Syiah hanyalah bagian dari 'wisata riset' tanpa mempertimbangkan budaya kesopanan dan perasaan masyarakat lokal. Tegasnya, keberadaan mereka hanya sekedar objek pemuas kepentingan komunitas ilmiah yang tidak memberikan perubahan hidup yang lebih baik.

Itulah sebabnya, ketika Saya mencoba berkunjung ke desa Blu'uran untuk menulis tema pendidikan ini sebagian masyarakat di sana terkesan menutup diri. Tidak hanya warga desa pada umumnya, perangkat desa sekaligus aparatur pemerintah setempat juga seakan bungkam seribu bahasa dan mengacuhkan niat baik Saya. Namun, kebetulan atau tidak, Saya merasa beruntung karena salah satu keluarga dekat diundang mengisi acara pengajian oleh tokoh desa setempat. Pada saat itu, Saya sedang melakukan pendekatan dengan salah satu warga desa setelah berhari-hari di lapangan tidak mendapatkan akses data secara memadai. Setelah pengajian selesai, dari kejauhan kerabat dekat yang dikenal sebagai 'kyai kampung' itu melihat Saya dan dia berusaha menghampiri Saya.

Pasca pertemuan yang tidak direncanakan saat momentum keagamaan itu, warga desa mulai berubah sikapnya. Perlahan namun pasti, beberapa data dokumentasi dan wawancara yang diperlukan untuk riset sederhana dan berbiayai mandiri ini mudah ditelusuri. Namun, data dokumentasi yang berkaitan dengan profil desa sangat sulit didapatkan. Karena mungkin lokasi desa yang jauh dari pusat pemerintahan, baik kota dan kecamatan, membuat daerah ini terkendala terkait masalah informasi dan pengetahuan pembuatan dokumentasi desa. Terlebih lagi, sebagian besar masyarakat yang suka merantau ke luar desa dan pulaunya untuk bekerja saat aktivitas pada bidang pertanian dianggap kurang menguntungkan juga menjadi hambatan tersendiri dalam urusan pengorganisiran data dokumentasi desa. Karena itu, untuk melengkapi hasil akhir penelitian ini Saya mencoba melacak data dokumentasi Madura yang banyak tersedia secara tekstual. Harapannya akan memberikan kerangka umum mengenai deskripsi geografis, demografis, dan sosial historisnya.

Sedangkan, data wawancara secara intensif dilakukan terhadap dari dua sesepuh desa, dua guru senior di lembaga pendidikan setempat, dan dua orang tua siswa yang anaknya bersekolah di SDN 2 Blu'uran. Waktu wawancara ini dilakukan secara fleksibel dengan mempertimbangkan ketersediaan waktu luang masing-masing informan. Sedangkan, lokasi wawancara dilakukan di tempat tinggal mereka.
Karena, tradisi orang Madura terutama orang desa selalu memberikan suguhan makanan yang diolah sendiri sebagai bentuk menghormati tamu dan menciptakan suasana keakraban dengan tuan rumahnya. Wawancara yang semacam inilah menguntungkan karena tatkala menyambut tamunya para tuan rumah di daerah ini kerap mengikutsertakan para tetangga dan sanak saudaranya. Sehingga, banyak orang yang turut terlibat memperkaya dan melengkapi informasi yang Saya butuhkan ketika proses wawancara berlangsung. Tetapi, yang mesti diperhatikan bahwa teknik wawancara konfrontasi secara terbuka di depan banyak orang sebaiknya tidak perlu dilakukan di tengah masyarakat rawan konflik dan menjungjung tinggi tatakrama. Apalagi, peneliti berusaha menggurui. Apabila hal itu terjadi, maka suasana wawancara akan menjadi kaku dan imbasnya pada pendalaman data yang ingin digali. Ketika peristiwa tidak menyenangkan ini terjadi, maka kabar buruk itu akan segera menyebar luas ke masyarakat desa lainnya. Hal ini tentu saja akan menghambat proses penelitian, selain juga bisa mengancam keselamatan para peneliti.

\section{HASIL DAN PEMBAHASAN}

\section{Sosial Geografis Pulau Madura}

Pulau Madura terletak di sebelah timur laut pulau Jawa dengan koordinat $7^{\circ}$ lintang selatan dari khatulistiwa, dan antara $112^{\circ}$ dan $114^{\circ}$ bujur timur. Panjang pulau Madura kurang lebih 190 $\mathrm{km}$, jarak terlebar $40 \mathrm{~km}$ dan luas keseluruhan $5.304 \mathrm{~km}^{2}$. Ketinggian Madura dari permukaan laut berkisar antara 2 hingga 350 meter. Antara Jawa dan Madura dipisahkan oleh selat Madura. Madura termasuk wilayah administratif provinsi Jawa Timur (Jatim), dengan memiliki 4 (empat) kabupaten. Menurut letak, historis, dan wacana yang berkembang di masyarakat setempat, empat kabupaten itu diklasifikasikan menjadi Madura Barat (Bârâ') meliputi Kabupaten Bangkalan dan Sampang, dan Madura Timur (Tèmor) yang meliputi Pamekasan dan Sumenep.

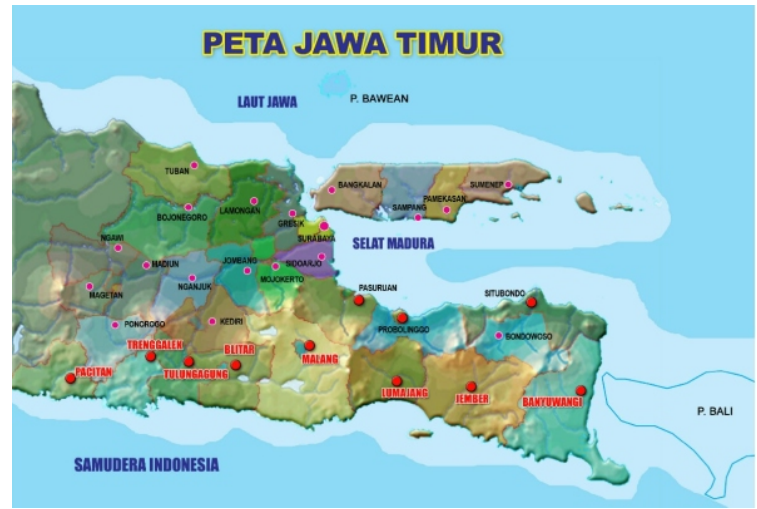

Gambar 2. Sampang-Madura dalam Peta Jawa Timur 
Sekalipun demikian, sekilas kondisi sosialbudaya Barat dan Timur pulau Madura sepertinya tidaklah jauh berbeda (Wiyata, 2002:29).

Dari aspek kewilayahan, Sumenep merupakan kabupaten terluas di antara empat kabupaten lainnya. Luas masing-masing kabupaten tersebut adalah: Bangkalan $1.260 \mathrm{~km}^{2}$, Sampang 1.233 $\mathrm{km}^{2}$, Pamekasan $792 \mathrm{~km}^{2}$, serta Sumenep 1.989 $\mathrm{km}^{2}$. Total luas lahan di Madura adalah 469,590 ha, dengan rincian: Bangkalan 116,607 ha, Sampang 123,084 ha, Pamekasan 77 ha, dan Sumenep 152,104 ha (Neihof, 1948).

Madura tergolong wilayah tropis dengan dua musim, yakni penghujan (nambhârâ') dan musim kemarau (nèmor). Musim penghujan (nambhârâ') berlangsung mulai pertengahan November hingga permulaan April, dan ketika itu suhu udara berkisar pada angka $28^{\circ} \mathrm{c}$ dengan jumlah hujan turun rata-rata 16 hari/bulan, dan curah hujan sekitar 200-300 mm. Sedangkan musim nèmor, terjadi pada Mei hingga pertengahan Oktober, dengan suhu rata-rata $30^{\circ} \mathrm{c}$. Pada saat ini, suhu udara biasanya sangat panas dan sebagian besar sungai mengering. Ketika musim pancaroba, ratarata curah hujan sekitar $100 \mathrm{~mm} /$ bulan. Daerah pedalaman yang lebih tinggi hampir selalu mengalami musim nambhârâ' lebih lama. Namun, daerah yang lebih rendah, musim nambhârâ'berlangsung relatif lebih singkat.

Sebagian masyarakat dari luar Madura menganggap Madura merupakan bagian dari sekian banyak pulau di Jawa dengan memiliki kondisi alam yang kurang menguntungkan dari sektor pertanian (Kuntowijoyo, 2002). Dibandingkan daerah Jawa, pulau Madura memiliki kondisi lahan yang tandus dan kurang subur bagi aktivitas pertanian. Karena, permukaan tanah di Madura didominasi oleh susunan batu kapur dan endapan kapur, dengan lapisan aluvial laut di sepanjang pantai utara dan empat dataran aluvial sungai (satu di barat, dua di selatan, dan satu di timur). Terutama Madura bagian timur (Sumenep dan Pamekasan), seluruh tanahnya terdiri dari batu nepal dan juga kapur, ditambah dengan batu alam lainnya yang sangat keras (De Jonge, 1989). Tanaman yang mudah tumbuh di daerah itu adalah jagung, singkong, ketela pohon, ubi, dan beberapa tanaman palawija yang mengandalkan air bawah tanah. Tanaman populer di Madura adalah tembakau, bambu, kesambi, duwet, kenari, dan lain-lain. Khusus tembakau, cara penanamannya tidak mudah. Guna menghasilkan tanaman tembakau yang berkualitas diperlukan perawatan yang amat intensif dan pemupukan yang hati-hati (Kuntowijoyo, 2002:59). Meskipun belakangan ini masyarakat Madura Barat menganggap tembakau bukan lagi sebagai tanaman yang menjanjikan. Selain pertimbangan resiko alam, tembakau juga menjadi komoditas politik yang tidak berpihak kepada rakyat. Bahkan, pihak swasta di Madura cenderung mempermainkan harga tembakau demi kepentingan ekonomi politiknya (Zamroni, 2006). Pada kasus ini, barangkali tesis Mosher (1977) relevan bahwa kebanyakan keputusan petani akan kelangsungan pertaniannya diambil dalam kedudukannya sebagai anggota keluarga, dan bukan sebagai anggota aktif dalam sistem bisnis pertanian.

\section{Sosial Agama Orang Madura}

Mayoritas masyarakat Madura beragama Islam yang tergolong penganut yang taat dan fanatik. Berbagai aktivitas sosial masyarakat selalu dikaitkan dengan nilai-nilai keislaman (Rozaki, 2004:3). Termasuk juga, aktivitas politik dan pendidikan. Agama Islam merupakan basis identitas utama untuk membedakan adanya perilaku kompromistis yang dianut orang Jawa (Lombard, 2000: 36). Sebagai unsur identitas kultural, agama menjadi bagian integral dari harga diri orang Madura. Sehingga, ada ungkapan umum di kalangan masyarakat desa: "sebodoh-bodohnya orang Madura, bila ada yang menghina agama dan tradisinya, mereka akan marah untuk membela diri".

Persoalan kefanatikan masyarakat Madura terhadap agamanya juga tidak lepas dari kondisikondisi alam yang mengelilinginya, yang kemudian berperan ke dalam pembentukan perilaku sosial masyarakatnya. Di Madura, kebanyakan desa mempunyai pola desa tersebar (scattered village), dimana perumahan penduduk terpencar dalam kelompok-kelompok kecil lima atau enam keluarga, yang dikelilingi oleh tanah tegalan. Dari ekosistem tegalan seperti itu bisa dipahami bahwa masyarakat yang tidak memiliki banyak waktu bekerja sama dalam mengatur pengairan desa, maka tidak akan mempunyai tingkat solidaritas desa yang tinggi. Kondisi desa yang memencar menambah sulitnya masyarakat desa untuk menjadi sebuah satuan teritorial dan sosial. Guna mempersatukan desa-desa yang tepencar diperlukan adanya organisasi sosial yang membentuk ikatan solidaritas. Karena desadesa tidak dipersatukan dalam suasana ekonomi, maka sistem simbol menjadi lebih kuat. Karena kondisinya yang terpencar-pencar, perlu ada pengikat yang menjembatani pemecahan desa ini. Dalam konteks ini, agama menjadi "organizing principle" bagi orang Madura. Agama memberikan collective sentiment melalui ritual ibadah sebagai penguat simbolik (Kuntowijoyo, 1993: 86). Misalnya, orang membangun masjid desa untuk mengikat tali persaudaraan di antara orang Madura melalui ritual syariat Islam, tradisi maupun pendidikan keagamaan di masjid desa. Masjid maupun 
musholla di desa juga berfungsi sebagai media informasi warga desa. Karena TOA (alat pengeras suara) di masjid selain berguna sebagai petunjuk masuknya waktu sholat lima waktu juga bermanfaat untuk mengumumkan adanya orang meninggal dunia, kegiatan desa, pengajian rutin, posyandu, termasuk panggilan kepada seseorang karena urusan genting dan mendesak.

Identitas agama tersebut turut serta membuat masyarakat Madura menjadi masyarakat dengan pembentukan organisasi sosial yang didasarkan sentimen agama. Sehingga, di sanalah otoritas kiai cenderung lebih tinggi dibandingkan tokoh masyarakat lainnya. Masyarakat sipil yang dibangun di atas organisasi desa tidak lebih sebagai organisasi supradesa biasa, namun tidak mempunyai pengaruh cukup kuat tanpa ditopang oleh basis keagamaan. Sebagaimana kultur patrimonial, posisi kiai sebagai pemimpim kultural terasa sangat mendominasi kehidupan masyarakat Madura. Artinya, kekuasaan di Madura terpusat pada figur sentral keagamaan yang secara tradisional keberadaannya sangat dibutuhkan untuk menjaga tatanan kehidupan masyarakatnya. Hal ini akan berimbas pada perubahan diferensiasi peran kiai di Madura, yang mulanya hanya terkosentrasi pada wilayah keagamaan saja kemudian meluas ke wilayah politik, ekonomi, dan pendidikan juga.

Di Madura, sebagai salah satu daerah basis terbesar NU di Jawa Timur, juga banyak berdiri pondok pesantren, baik yang masih tradisional ataupun yang telah menyandang gelar "pondok modern". Setiap kecamatan setidaknya minimal terdapat satu pondok pesantren. Umumnya, pondok pesantren di daerah pedesaan memang masih sangat kental dengan sistem pendidikan agama tradisional yang tetap mempertahankan pengajaran buku-buku teks Islam klasik (seperti, kitab kuning) dan penerapan metode-metode pengajaran madrasah. Sebagian lainnya telah berkembang menjadi pesantren modern yang di dalamnya memuat pelajaran keagamaan dan umum secara bersamaan, selain juga mengadopsi sistem kelas berjenjang dan pemberian ijasah formal. Jenis pondok ini mengklaim dirinya sekolah agama plus, yang lazim disebut "Madrasah Diniyah", "Madrasah Tsanawiyah", dan "Madrasah Aliyah".

Pondok pesantren, dengan figur kyai sebagai pemegang puncak kepemimpinan memang ibarat kiblat bagi masyarakat desa. Setiap hari, selain melakukan kegiatan membina umat, mengajarkan ilmu pada para santri, biasanya kiai juga mendapatkan kunjungan orang-orang yang meminta doa atau sekadar mengharap berkah (Wiyata, 2002: 49). Dalam stratifikasi sosial masyarakat Madura, kiai memang merupakan kelompok masyarakat di lapisan sosial teratas, bahkan di atas bupati. Pengetahuan yang mendalam tentang Islam menjadikan mereka sosok paling dekat dengan tuhan sehingga posisinya sangat terhormat di masyarakat.

Selain kiai, pelapisan sosial berdasarkan agama juga meliputi santri sebagai lapisan terbawah, dan bindarah/lora sebagai lapisan menengah. Bindarah/lora merupakan keturunan kiai yang telah menamatkan pendidikan pondok pesantren, memiliki pengetahuan keagamaan yang melampaui para santri, tetapi masih belum setaraf kemampuan kiai. Dalam kehidupan sehari-hari masyarakat Madura, bindarah/lora juga diperlakukan hampir sama seperti kiai karena darah keturunan kiai melekat padanya.

Secara sosial pendidikan, sosok terhormat selain kedua orang tua dan kiai adalah guru dalam arti umum. Tidak semua masyarakat mematuhi guru sekuat orang Madura (Wiyata, 2002). Meski guru di sekolah umum memberikan ilmu pengetahuan modern yang berurusan dengan hal keduniawian, mereka juga bagian dari lapisan sosial tertinggi di Madura karena kontribusinya yang besar bagi upaya pencerdasan kehidupan bangsa. Guru dianggap suri teladan karena selain memberikan wawasan dunia dan mengasah logika mereka menanamkan juga nilai-nilai tatakrama dan ahlak bagi murid-muridnya. Hal ini sesuai dengan ajaran Islam bahwa ahlak merupakan kriteria utama seseorang terdidik atau tidak. Begitu pentingnya peran guru bagi kehidupan murid-muridnya membuat orang tua di Madura tidak segan menghukum anakanaknya yang berlaku tidak sopan dan tidak hormat kepada gurunya. Bahkan, jika ada anakanak yang mengadukan hukuman guru selama di sekolah kepada orang tuanya, justru anakanaknya akan diberi hukuman tambahan. Anggapan orang tua di Madura bahwa tidak mungkin guru sewenang-wenang menghukum seorang muridnya jika muridnya tidak berlaku kurang ajar (korang ajher) dan nakal (meller) di lingkungan sekitarnya.

\section{Bersekolah Tanpa Pengharapan}

Apabila bertanya kepada sebagian orang tua di perkotaan tentang harapan anak-anak mereka disekolahkan, maka jawaban yang didapatkan tampak terang benderang. Yang paling umum jawabannya adalah ingin anak-anaknya menjadi lebih baik dari kehidupan sosial orang tuanya. Terutamanya kesuksesan di dunia kerja dan kemapanan ekonominya. Umumnya, orang tua dan anak-anaknya memiliki suara yang sama dalam menentukan profesi pekerjaan di masa depan, seperti menjadi dokter, pegawai negeri, guru, dosen, dan pekerjaan lainnya yang menjanjikan. Di alam pikiran dan imajinasi mereka hampir tidak pernah terbesit untuk ingin 
menjadi petani, nelayan, buruh, terlebih lagi pengangguran yang dianggap sebagai status sosial rendahan. Meskipun kadangkala bisa saja meleset dari rencana awal, setidaknya cita-cita dan pengharapan menjadi daya semangat anakanak mereka bersekolah. Bagi sebagian besar orang tua perkotaan, tujuan akhir menempuh pendidikan formal anak-anaknya tampak lebih nyata daripada orang tua di daerah pedesaan.

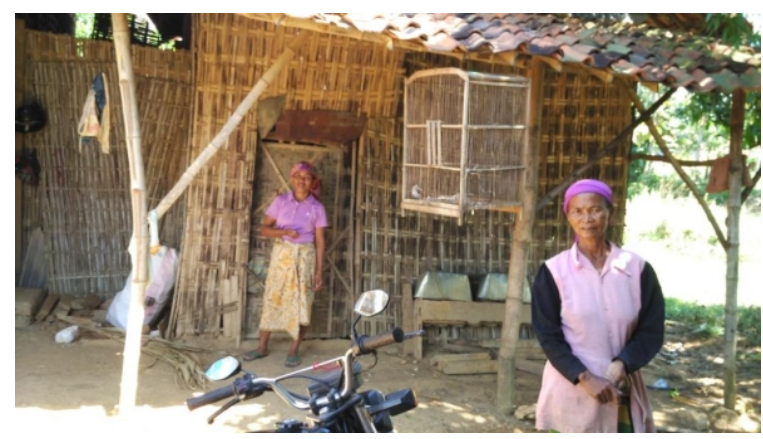

Gambar 3. Salah Satu Orang Tua Siswa dan Kondisi Rumahnya (Sumber: dokumen pribadi)

Di desa Blu'ran, terutama para orang tua siswa di sekolah dasar negeri Blu'uran 2, pada umumnya tidak memiliki pengharapan ketika anak-anaknya disekolahkan. Ketika Saya bertanya kepada salah satu orang tua siswa tentang cita-cita yang digantungkan kepada anakanaknya setelah tamat sekolah justru jawabannya terkesan tidak rasional. Baginya, urusan masa depan, sekaligus pekerjaan dan kehidupan ekonomi yang layak, tidak ada kaitannya dengan campur tangan manusia, karena ini urusan tuhan semata. Sayyidah (36 tahun) yang sehari-harinya bekerja sebagai buruh tani mengatakan bahwa nasib masa depan anaknya bergantung penuh pada misteri tentang keberuntungan yang disebut bhejreh/pojur. Karena itulah, dia tidak memikirkan, apalagi merencanakan cita-cita anaknya sejak semula. Baginya, anaknya mau bersekolah saja sudah beruntung. Meskipun, dia tidak pernah tahu bagaimana proses belajar mengajar yang diterima anaknya di sekolah. Dia tidak punya waktu untuk mendampingi aktivitas pendidikan dan belajar anaknya, baik di sekolah maupun di rumah. Sehari-harinya dihabiskannya bekerja di sawah secara serabutan dengan imbalan bulir padi ataupun uang yang tidak seberapa banyak jumlahnya. Jika sedang tidak ada sawah garapan, Ia bekerja sebagai buruh pembuatan genting (ghentèng) di desanya dengan bayaran setiap harinya berkisar antara 20-40 ribu.

Sayyidah tinggal bersama ibunya dan kedua anaknya yang berusia sekolah dasar. Pendidikan formalnya dijalaninya hingga kelas tiga, lalu memutuskan berhenti bersekolah karena tuntutan pernikahan dini. Suaminya yang tidak tamatan sekolah dasar menjadi TKI (Tenaga Kerja Indone- sia) sebagai buruh bangunan di Malaysia. Setiap bulannya, selain mengandalkan hasil kerja buruh serabutan, dia juga mendapatkan uang kiriman bulanan dari Malaysia antara 2-4 juta rupiah. Tetapi, kiriman ini tidak menentu waktunya, bahkan dalam satu tahun kiriman itu tidak kunjung datang. Dalam kondisi keterbatasan ekonomi ini, Ia juga tidak bisa berharap banyak untuk membiayai sekolah kedua anaknya. Awalnya, kedua sang anak bersekolah Madrasah Ibtidaiyah (MI) di pondok pesantren setempat. Kemudian, kedua anaknya pindah ke SDN Blu'uran 2 dengan alasan belajar baca tulis bahasa Indonesia dengan baik. Berdasarkan penuturannya bahwa kemampuan baca tulis tersebut bisa membantunya pada saat mengisi berkas-berkas administrasi yang dibutuhkan keluarga seperti kartu tanda penduduk. Termasuk, bekal berkomunikasi dengan orang lain saat anaknya berkeinginan merantau ke luar Madura.

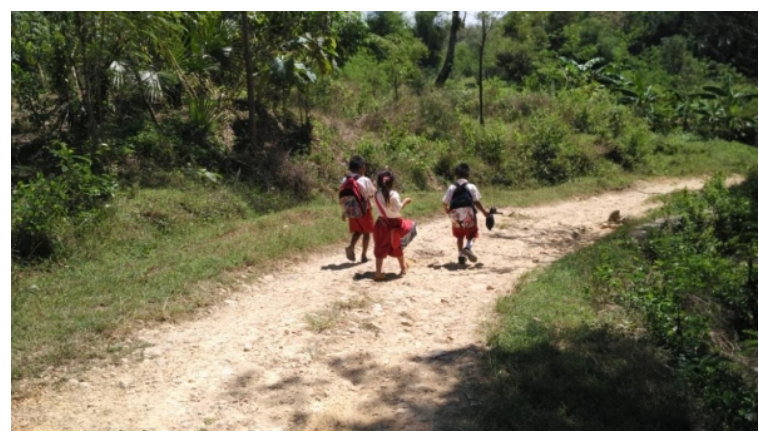

Gambar 4. Siswa SDN Blu'uran 2 berjalan kaki menuju ke Sekolah (Sumber: dokumen pribadi)

Beruntung pihak sekolahnya memberikan alat perlengkapan sekolah secara cuma-cuma, mulai dari seragam, buku tulis dan pelajaran, hingga sepatu. Meskipun begitu, setiap harinya keduanya selalu membawa seragam dan alat perlengkapan mengaji ke sekolahnya yang kesemuanya dimasukkan ke dalam tas plastik seadanya dan ditententeng sesukanya. Sudah menjadi tradisi setiap jam satu siang mereka dituntut orang tuanya untuk mengaji ke langgar (surau) yang lokasinya tidak jauh dari sekolahnya. Jarak rumahnya ke sekolah yang sangat jauh tidak memungkinkan menyegerakan diri mereka pulang terlebih dahulu untuk agenda mengaji. Keduanya harus berjalan kaki saat bersekolah dengan jarak tempuh sekitar $4 \mathrm{Km}$. Jika mereka berangkat dari rumahnya sekitar jam enam pagi, maka tiba ke sekolahnya sekitar jam setengah delapan pagi. Sehingga, urusan terlambat masuk kelas sudah menjadi rutinitas harian mereka. Sementara, para guru di sekolah bisa memahami dan memakluminya karena kondisi sosial geografis mereka. Para guru di sana sangat realistis dan empatik kepada kondisi 
para siswanya. Selain kemiskinan ekonomi keluarga, tekanan sosial yang mereka hadapi juga tidak kalah hebatnya. Di sisi yang lain, kehilangan siswa di sekolahnya karena tuntutan normatif yang terlalu kuat merupakan kekhawatiran dan beban moral tersendiri dari para guru di sana. Sebagaimana disampaikan oleh Maduh ${ }^{1}$ (69 tahun), guru olah raga di SDN Blu'uran 2:

"Kami para guru tidak bisa berbuat banyak. Berbagai aturan dari pusat terkadang bias perkotaan. Sementara, kami yang berhadapan dengan kondisi masyarakat desa yang sangat tertinggal sadar betul betapa sulitnya menerapkan aturan baku kepada para siswa. Saat mereka datang ke sekolah, tanpa diantar, melewati sawah dan bukit-bukit sepi dengan berjalan kaki penuh nyali, sudah menjadi kebahagiaan tersendiri bagi kami. Jika kami memaksakan akumulasi standar normatif kepada mereka, kami akan kehilangan kemauan bersekolah mereka selamanya.

\section{Orang Pintar (Rèng Pènter) dan Orang Untung (Rèng Pojur)}

Pintar saja tidak cukup dalam pendidikan. Bagi para guru dan orang tua siswa yang Saya temui di lokasi penelitian kerapkali menyebutkan bahwa sekolah mampu membentuk orang pintar (rèng pènter), tetapi tidak dengan orang untung (Pojur atau Bhejreh). Ciri utama orang pintar adalah keinginan yang kuat untuk belajar tekstual (baca-tulis) dan memenuhi target materi persekolahan, sedangkan orang untung tidak demikian. Ciri paling menonjol orang untung terletak pada kemampuannya memahami kehidupan agama dan mendapatkan sesuatu berharga tanpa disangka-sangka. Menjadi orang pintar lebih mudah dibandingkan menjadi orang untung. Kepintaran seseorang bisa didapatkan melalui jalur pendidikan, tetapi keberuntungan seseorang didapatkan dengan memperbanyak kebaikan dan kemaslahatan.

Kesuksesan orang pintar itu berjangka pendek (juara kelas dan lulus sekolah dengan nilai tinggi), tetapi kesuksesan orang untung berdimensi jangka panjang (hidup berkecukupan lahir batin dunia akherat). Bisa saja ketika menjalani proses pendidikan formal seseorang tergolong biasa saja, bahkan tertinggal dibandingkan teman-teman sebayanya. Setelah lulus sekolah nanti tidak menutup kemungkinan dia tergolong orang berpengaruh dan terpandang baik dari segi ekonomi, sosial terlebih lagi agamanya. Ekonomi juga bukan ukuran beruntung tidaknya seseorang. Sangat boleh jadi orang miskin lebih dicintai tuhan dan lebih mudah masuk surga daripada orang kaya, apalagi kayanya karena korupsi. Orang pintar diibaratkan menanam padi, sementara orang untung seperti menanam pohon jati. "Orang pintar masa panennnya seusia tanaman padi, sedangkan orang untung masa panennya seusia pohon jati", kata penjaga sekolah SDN Blu'uran 2, Nahraji (42 tahun). Bagi orang desa, menjadi orang untung lebih didambakan daripada orang pintar. Maka, bagi mereka bersekolah bukan satu-satunya jalan pendidikan sesungguhnya. Karena tidak ada jaminan bahwa sekolah bisa memberi kepastian masa depan anak-anak mereka. Bagi orang tua siswa', selain kemampuan baca-tulis, bersekolah hanya sekedar mencari ijasah yang nantinya diperlukan anak-anaknya untuk kelengkapan formal dan menambah gengsi sosial (lulus sekolah dan pernah bersekolah seperti orang kebanyakan).

\section{Berebut Siswa: Sekolah Umum Vs Pesantren}

Lokasi SDN Blu'uran 2 bersebelahan dengan Pondok Pesantren Nagasari Congkop. Orang sekitar menyebut kedua lembaga pendidikan ini secara sederhana: sekolah umum dan pondok (sekolah berbasis agama Islam). Sebagai bagian dari kultur masyarakat Madura yang kental dengan keIslamannya, maka posisi pondok memiliki pengaruh yang luar biasa. Orang di desa lebih taat dan percaya kepada para Kyai setempat. Apalagi, Kyai bersangkutan adalah pimpinan pondok. Di sisi yang lain, rasa hormat mereka kepada para guru (termasuk guru sekolah) juga bagian tidak terpisahkan dari budaya Madura. Kyai maupun guru sekolah tetap diposisikan sebagai tokoh panutan orang Madura selain kedua orang tua dan pemimpin yang bijaksana sebagaimana yang tercermin dari ungkapan sehari-hari tentang buppak-bhabhuk ghuru ratoh. Meskipun dalam sejarahnya budaya penghormataan ini bentukan kolonial, tapi orang Madura pada umumnya mengukuhkannya sebagai bagian dari kehidupan sosial mereka yang sudah mengakar tanpa perlu dipersoalkan (Raditya, 2016).

Namun, urusan lembaga pendidikan terjadi kompetisi yang sengit dalam hal berebut siswa. Kedua pihak, baik sekolah umum dan pondok saling menyudutkan satu dan lainnya dengan berbagai macam wacana yang dapat memicu emosional dan pengukuhan stigmatik orangorang desa. Yang patut disesalkan pula adalah para siswa dari kedua lembaga yang masih berusia sekolah dasar turut terpancing dengan pengaruh buruk tersebut. Bahkan, siswa-siswa

\section{Berdasarkan data profil sekolah menunjukkan}

bahwa $80 \%$ pekerjan orang tua siswa sebagai buruh tani, yang didominasi dengan buruh tani (Sumber: data peserta didik yang telah diolah kembali). 
saling mencemooh di antara mereka. Bagi siswa MI, sekolah umum dipandang sebagai terlalu mengedepankan urusan dunia karena minimanya pendidikan dan pelajaran agama. Bagi siswa sekolah umum, MI dianggap kurang mengandalkan pengetahuan umum karena itu dianggap monoton dan membosankan. Tetapi, dari segi jumlah siswa sekolah umum memang lebih sedikit dibandingkan MI. Di SDN Blu'uran 2 saja, setiap tahunnya rata-rata jumlah siswanya tidak lebih dari 100 orang. Terkadang, jumlah siswa di kelas satu yang membludak hingga melebihi kapasitas ruangnya ternyata di kelas enam justru menurun drastis hingga separuh lebih. Menurut informasi para guru sekolah bahwa penurunan itu disebabkan oleh dua hal. Pertama, adanya indikasi taktik kecurangan pihak MI dalam berkompetisi. Pihak MI menyuruh siswanya bersekolah ke sekolah umum hingga tahu baca tulis, biasanyanya hingga kelas tiga. Setelah kemampuan dasar itu dimiliki siswa, maka mereka lantas pindah sekolah ke MI. Kedua, para siswa sengaja berhenti sekolah karena adanya tuntutan keluarga, semisal membantu orang tuanya di sawah, menjaga adikadiknya di rumah, dipaksa menikah, dan mengikuti orang tuanya yang bekerja di luar Madura.

Ironisnya, para siswa MI kadangkala mengganggu proses belajar mengajar di sekolah umum. Dua hingga empat orang siswa MI secara terang-terangan berdiri di depan pintu kelas sambil berbicara dengan suara nyaring kepada teman-temannya saat guru sedang mengajar. Tidak ada satupun guru yang berani menghentikan secara tegas tindakan siswa MI ini karena khawatir akan menyulut konflik dan kekerasan yang mengancam keberadaan mereka di desa orang lain. Apalagi, mereka berhadapan dengan lingkungan pedesaan yang secara pendidikan masih terbelakang dan kesadaran orang-orangnya terhadap sekolah umum masih tergolong minim. Didukung pula fanatisme sempit terhadap pendidikan agama dan tokoh agama yang begitu terasa kental.

Oleh sebab itu, atas inisiatif guru-guru di sana jam sekolah dibatasi hingga jam 11.00 WIB. Sebab, setelah itu para siswa sekolah umum harus belajar mengaji. Pernah dalam suatu kesempatan seorang guru baru di SDN Blu'uruan 2 mengajar hingga sesuai jam pelajaran sekolah umum sebagaimana mestinya. Esok harinya, para siswanya tidak lagi kembali bersekolah dan ruang kelasnya menjadi kosong. Ada semacam tekanan berbentuk hukuman kekerasan yang dilakukan oleh lembaga tempat para siswa mengaji apabila mereka terlambat ataupun tidak mengaji karena alasan kepentingan sekolah umum. Para orang tua mereka juga tidak bisa berbuat banyak karena selain dicemooh orang sekitar sebagai orang yang tidak mengedepankan agamanya juga takut akan mendapatkan musibah gaib (ètolaèh) karena tidak taat pada Kyai. "Apabila agama dikedepankan, maka urusan dunia akan lebih mudah didapat (mon aghema è pakaade', dunnyah noro' buntè')" kata Pak Mat (55 tahun) seorang sesepuh desa.

\section{KESIMPULAN}

Pendidikan kaum tertinggal bukan sekedar proses belajar mengajar berlangsung baik. Menyederhanakan pendidikan hanya terbatas pada efektifitas belajar di kelas sesungguhnya tidak membuat masyarakat terdidik dan berkualitas dari aspek sumber daya manusianya. Di tengah kondisi hidup masyarakat daerah tertinggal seperti halnya di Sampang membutuhkan perhatikan khusus dalam memandang, memahami, sekaligus mengelola proses pendidikan di sana. Kondisi hidup masyarakat yang dipenuhi oleh tekanan sosial, budaya, dan geografisnya merupakan kendala utama yang harus diselesaikan agar pendidikan mampu berjalan sesuai harapan pemangku kebijakan pendidikan nasional. Pendidikan kaum tertinggal di Sampang dapat tergolong sebagai gejala anomali khusus dalam sistem pendidikan nasional. Sehingga, keberhasilan praktik pendidikan di daerah lain, terutama di perkotaan tidak mudah diterapkan di daerah kaum tertinggal seperti halnya di Sampang, terutama di daerah rawan konflik sosial keagamaan sebagaimana halnya di desa Blu'uran.

Boleh jadi pendidikan di sana diposisikan sebagai sebuah fenomena pendidikan kaum tertindas karena massifnya kekuatan kesadaran magis dan naif sebagian besar masyarakatnya. Sehingga, mereka tidak berdaya melakukan transformasi sosial karena masih terjebak pada budaya bisu. Sekalipun demikian, tokoh sentral pendidikan yang memiliki basis keagamaan dan budaya lokal, semisal kiai, guru, dan orang tua Madura, punya peran besar mendorong anakanak Madura untuk bersekolah. Mereka masih memiliki keinginan supaya anak-anak Madura bisa meraih kehidupan yang lebih baik dari generasi terdahulunya. Namun, orientasi masa depan ini tidak ditopang oleh komitmen yang besar. Ketika mereka dihadapkan pada situasi pragmatis, semisal, upaya bertahan hidup keluarga dan konflik sosial keagamaan yang tidak kunjung reda, maka orientasi pendidikan tersebut tiba-tiba berubah drastis. Sehingga, makna pintar (pènter) sebagai kriteria umum pendidikan tak lagi menjadi acuan utama karena masyarakat memasukkan keberuntungan (pojur) sebagai kriteria alternatif agar mereka tidak terlalu berharap banyak pada janji manis pendidikan. 
Sepintas, komitmen yang besar merajut masa depan pendidikan anak-anak Madura tampak terlihat dari dorongan para kiai dan guru mengajak para orang tua untuk menyekolahkan anak-anaknya. Kenyataannya, masing-masing dari figur sentral pendidikan masyarakat Madura ini memiliki kepentingan politis. Karena tujuannya bukan dalam rangka membuat anakanak Madura lebih baik dari kehidupan orang tuanya, melainkan untuk memenuhi standar kuantitas jumlah murid dan siswa di lembaga pendidikan masing-masing sebagai bentuk ketaatan mereka terhadap standar mutu kebijakan pendidikan. Dengan kata lain, keberhasilan pendidikan hanya semata-mata dimaknai sebagai banyak tidaknya jumlah murid dan siswa yang terdaftar di sekolah umum dan pesantren. Itulah sebabnya, kompetisi di antara para figur sentral pendidikan di Sampang Madura terasa sengit, menegangkan, dan penuh intrik untuk saling menjatuhkan. Hal ini terkadang membuat mereka lupa atau mungkin pura-pura lupa bahwa masalah terbesar di daerah kaum tertinggal bukan berada di dalam kelas, melainkan menyebar di luar kelas, termasuk di dalamnya cara para figur kultural Madura memaknai pendidikan masyarakat setempat.

\section{DAFTAR RUJUKAN}

A.T, Mosher. (1977). Menggerakkan dan

Membangun Pertanian, Jakarta: CV Yasaguna

Niehof, Anke. (1958). Women And Fertility in Madura (Indonesia), Leiden: KITLV

Rozaki, Abdur. (2004). Manabur Kharisma, Meпuai Kuasa, Yogyakarta: Galang Press

Zamroni, Imam. (2006). Dinamika Kekuasaan Elite Ekonomi Lokal Pasca Soeharto di Pamekasan Madura, Tesis Pascasarjana Sosiologi UGM: Tidak dipublikasikan

Wiyata, A. Latief. (2002). Carok: Konflik Kekerasan dan Harga Diri Orang Madura, Yogyakarta: LKIS

Kuntowijoyo. (1993). Radikalisasi Petani, Yogyakarta: Bentang (2002). Madura (1850-1940), Yogyakarta: Mata Bangsa

Lombard, Denys. (2000). Nusa Jawa Silang Budaya, Jakarta: PT. Gramedia

Raditya, Ardhie. (2016). Pendidikan Anti Pendidikan, Surabaya: Unipress

Clark, Moustakas. (1994). Phenomenological Research Methods, California: SAGE

Lexy J. Moleong. (2000). Metode Penelitian Kualitatif, Bandung: Remaja Rosda 